\title{
Short, medium or long-term hormonal treatments for induction of synchronized estrus and ovulation in Saanen goats during the nonbreeding season
}

\author{
Ana Carolina Cunha Araujo Pietroski ${ }^{1}$, Felipe Zandonadi Brandão ${ }^{1}$, Joanna Maria Gonçalves \\ de Souza², Jeferson Ferreira da Fonseca ${ }^{3}$
}

\footnotetext{
${ }^{1}$ Faculdade de Veterinária da Universidade Federal Fluminense, Rua Vital Brasil Filho, 64, CEP 24230-340, Santa Rosa, Niterói, RJ, Brazil.

2 Laboratório de Fisiologia e Controle da Reprodução, Faculdade de Veterinária, Universidade Estadual do Ceará, Av. Dedé Brasil, 1700 , CEP 60740-903, Itaperi, Fortaleza, CE, Brazil.

${ }^{3}$ Embrapa Caprinos e Ovinos, Estrada Sobral/Groaíras, km 04, CP 145, CEP 62010-970, Sobral, CE, Brazil.
}

\begin{abstract}
The objective of this study was to compare the effect of hormonal treatment duration through the use of intravaginal sponges impregnated with $60 \mathrm{mg}$ MAP for $6(\mathrm{G} 6 ; n=10), 9$ (G9;n=10) or $12(\mathrm{G} 12 ; n=10)$ days. All nulliparous $(n=15)$ and lactating $(n=15)$ Saanen goats received $37.5 \mu \mathrm{g}$ d-cloprostenol and 200 IU eCG 24 hours before sponge removal during the nonbreeding season. After sponge removal, estrus was monitored twice a day ( $06 \mathrm{~h} 00$ and $18 \mathrm{~h} 00$ ) by the use of fertile bucks. Transrectal ovarian ultrasonography was performed after device removal until ovulation detection. All goats were bred by artificial insemination (AI) or natural breeding (NB). All females received 250 IU hCG 5 d after AI or NB. No difference was observed among groups G6, G9 and G12 for: estrous response (90.0, 100.0 and 100.0\%, respectively); interval from sponge removal to estrus (26.7 $\pm 5.6,25.2 \pm 2.8$ and $25.2 \pm 3.3$ hours), duration of estrus (28.5 \pm 7.1 ; $21.6 \pm 3.0$ and $25.2 \pm 6.1$ hours); ovulation rate (80.0, 100.0 and $70.0 \%)$; number of ovulations $(1.9 \pm 0.2,1.5 \pm 0.2$ and $1.4 \pm 0.2)$; and pregnancy rate $(60.0,80.0$ and $50.0 \%)$. Interval from sponge removal to ovulation was shorter in animals from G6 (44.6 \pm 2.2 hours) than for animals from G9 (52.8 \pm 2.7 hours) and G12 (60.0 \pm 4.5 hours). All treatments were effective in the induction of synchronized estrus in Saanen goats during the nonbreeding season, but ovulation occurred earlier when goats received sponges for 6 days.
\end{abstract}

Key Words: estrous induction, goat, ultrasonography

\section{Introduction}

Goat production is experiencing a period of worldwide growth. This growth has intensified in recent decades, especially in developing countries, which hold the largest herds. Given the reproductive seasonality for this species, it is not always possible to obtain good results of kidding distribution throughout the year using natural estrus. Thus, estrus should be induced in the anestrous season and hormoniotherapy is a widely used technique for this purpose (Fonseca \& Simplício, 2008). In this context, artificial insemination (AI) can be scheduled and performed on a large number of females in the predetermined period. This allows does to kid during the whole year, resulting in a better scheduling of product offers to the consumer market. Therefore, synchronization and induction of estrus in goats allows for AI and reproduction management at any time of the year, facilitating the continuous availability of products such as milk and meat (Leboeuf et al., 1998).

Several hormonal protocols are used to induce estrus, as well as the use of artificial light, melatonin implants and male-effect (Fonseca \& Simplício, 2008). In order to achieve efficient estrous synchronization, progesterone (or analogues) is usually used (Romano, 2004). Progesterone has an inhibitory effect on the release of LH from the anterior pituitary so that it suppresses the endocrine events that influence the maturation of the ovarian preovulatory follicles and their later ovulation. Hence, following progestagen removal, estrus and ovulation occur at a predictable period of time (Dogan et al., 2004). During the breeding season it is crucial to use a luteolytic agent such as prostaglandin or its analogues (PGF $2 \alpha$ ) to eliminate potential corpora lutea. Moreover, the use of gonadotropin is critical, particularly during the nonbreeding season. Among the glycoprotein hormones, eCG is secreted by trophoblastic cells in the mare during gestation and is a convenient hormone to induce estrus and ovulation in goats due to its dual activity (FSH and LH) and long halflife (Hervé et al., 2004). Moreover, the use of hCG after breeding could also be implemented in the protocol in order to avoid fetal loss due its potent luteotropic or antiluteolytic effect in goats (Saharrea et al., 1998). 
Dairy goats are often inseminated after induction of a synchronized estrus at a predetermined time after the progestagen removal. When insemination is carried out in this way, the fertility of animals depends on the efficiency of the treatment to accurately control the occurrence of estrus and, therefore, of ovulation (Baril et al., 1996). Longterm treatment with intravaginal progestagen (10 to 18 days) has been shown to be associated with falling fertility (Viñoles et al., 2001; Diskin et al., 2002). A reduction in time of treatment with progestagens may facilitate handling and minimize the loss of implants, vaginal discharge and infection, without compromising fertility (Fonseca \& Torres, 2005; Souza et al., 2011). However, this subject still remains contradictory among researchers and more studies should be performed in order to investigate possible differences among treatments and also breeds. This study evaluated the effect of the duration of hormone treatment (6, 9 or 12 days) with progestagen implants during the seasonal anestrus on the ovulatory dynamics, sexual behavior and fertility of Saanen goats.

\section{Material and Methods}

This study was conducted during November and December of 2009 (nonbreeding season), in a commercial goat milk farm, located in the state of Minas Gerais, Brazil (latitude $21^{\circ} 35^{\prime} \mathrm{S}$, longitude $43^{\circ} 15^{\prime} \mathrm{W}$ and altitude of $484 \mathrm{~m}$ ). The climate is characterized as mesothermal Cwa, according to the Köppen classification, with dry winters and hot summers (Peel et al., 2007).

The goats were kept in an intensive system and were fed Pennisetum purpureum as forage and a balanced concentrate supplement was fed according to milk production (NRC, 2007). Mineralized salt (Caprinofós ${ }^{\circledR}$, Tortuga, Brazil) and drinking water were available ad libitum. This research was reviewed and approved by the Animal Care Committee of Universidade Federal Fluminense (UFF/0160-09).

As experimental animals, 30 Saanen goats (15 nulliparous and 15 lactating) were selected and equally allocated according to category, body weight (BW) and body condition score (BCS, range 1 to 5 ), respectively, into three treatments: G6 ( $n=10 ; 5$ nulliparous and 5 lactating; $48.8 \pm 4.0 \mathrm{~kg}$, BCS 2.7 \pm 0.1$)$, G9 ( $n=10 ; 5$ nulliparous and 5 lactating; $50.3 \pm 4.1 \mathrm{~kg}, \mathrm{BCS} 2.9 \pm 0.0)$ and $\mathrm{G} 12(n=10 ; 5$ nulliparous and 5 lactating; $53.0 \pm 4.3 \mathrm{~kg}$, BCS $2.7 \pm 0.1$ ).

All females were treated with intravaginal sponges containing $60 \mathrm{mg}$ medroxyprogesterone acetate (MAP Progespon $^{\circledR}$, Schering Plough Animal Health, São Paulo, Brazil). Sponges were removed after 6 (G6), 9 (G9) or 12 (G12) days. Twenty-four hours before sponge removal, $37.5 \mu \mathrm{g}$ d-cloprostenol (PGF 2 $\alpha$; Veteglan ${ }^{\circledR}$, Calier Laboratories Ltda, Minas Gerais, Brazil) and 200 IU eCG (Novormon 5000 ${ }^{\circledR}$, Sintex Industries Biochemistry, Buenos Aires, Argentina) were given. Both d-cloprostenol and $\mathrm{eCG}$ were given by injections in the latero-vulvar area. Additionally, 250 IU hCG (Vetecor 5000 ${ }^{\circledR}$, Calier Laboratories Ltda, Minas Gerais, Brazil) were administered $5 \mathrm{~d}$ after artificial insemination (AI) or the last natural mating (NM).

After sponge removal, estrus was monitored with the use of bucks twice daily and females were considered to be in estrus when they allowed to be mounted. Females displaying signs of estrus were bred by NM (total of 14; all lactating) or AI (total of $16 ; 15$ nulliparous and 1 lactating). Fertile Saanen bucks $(n=3)$ were used for approximately equal numbers of does from each treatment, with a buck:doe ratio of about $\leq 1: 5$. Females were mated every 12 hours from the onset of estrus to the end. For AI, semen doses from 5 bucks participating in the Brazilian progeny test (donated by Embrapa Goats and Sheep) were used. Artificial insemination was performed at a different time according to female estrus signs (48 hours or 60 hours after sponge removal) by the deep cervical insemination technique as previously described (Fonseca et al., 2007). Cervical mucus was evaluated during AI (range 1 to 5) (Fonseca \& Simplício, 2008).

Transrectal ovarian ultrasonography was performed in all 30 goats (by the same operator) every 12 hours after device removal until detection of ovulation or until 96 hours after device removal (if ovulation was not detected). All examinations were conducted with a B-mode transrectal ultrasonographic scanner with $6 \mathrm{MHz}$ transducer (ÁquilaPro $^{\circledR}$, Esaote Pie Medical, Maastricht, Netherlands). To facilitate manipulation of the transducer, it was taped to a PVC tube. Does were maintained in a standing position, fecal pellets were removed manually (with a finger) and $20 \mathrm{~mL}$ of carboxymethylcellulose gel were placed into the rectum with a syringe. Ovaries were located as previously described (Ginther \& Kot, 1994), and the number, diameter, and position of ovarian follicles $\geq 2.5 \mathrm{~mm}$ were recorded. The day of ovulation was defined as the day when the largest follicle previously identified was no longer detected. The preovulatory follicle diameter was considered the last measurement obtained before ovulation. Approximately $30 \mathrm{~d}$ after breeding, the same equipment was used to conduct ultrasonographic pregnancy diagnosis for all goats.

The following end points were determined: estrous response (number of does in estrus/number of treated 
does $\times 100$ ); interval to estrus (from sponge removal to first acceptance of mounting); duration of estrus (interval from the first to last acceptance of mounting); interval from sponge removal to ovulation; interval from onset of estrus to ovulation; ovulation rate (number of does with confirmed ovulation/number of does evaluated by ultrasonography $\times 100$ ); number of ovulations per doe; largest follicle diameter; pregnancy rate (number of pregnant does/number of does subjected to estrus induction treatment); prolificacy (average number of fetuses born per female); parturition rate (number of females kidding/number of pregnant females $\times 100$ ) and fetal loss rate (number of goats not pregnant after a positive diagnosis/number of pregnant goats $\times 100$ ) . Statistical analysis was performed using all tests with $\mathrm{P}<0.05$ considered significant. Non parametric variables expressed by percentage were analyzed by the use of the chisquare test. Parametric variables were submitted to one way analysis of variance and compared by SNK test by software SAEG (Sistema para Análises Estatísticas e Genéticas, version 8.1). Pearson correlation was used among variables. Nonparametric variables were analyzed by the use of the chi-square test. The results are described as mean $\pm \mathrm{SD}$.

\section{Results}

A total of 13 lactating goats were bred by NM because one female did not show estrus. One nulliparous goat was removed from the experiment due to intense vaginitis after sponge removal and thus was not subjected to AI. Ten females (nine nulliparous and one lactating) were inseminated 48 hours, and five nulliparous goats 60 hours, after sponge removal.

Of the 29 goats in estrus, $16(55 \%)$ and $13(45 \%)$ were initially identified in estrus at $06 \mathrm{~h} 00$ and $18 \mathrm{~h} 00$, respectively. The moment of ovulation was detected in 12 (48\%) goats in the morning and in $13(52 \%)$ at night.

There was no difference $(\mathrm{P}>0.05)$ among groups $\mathrm{G} 6$, G9 or G12 for sexual behavior end points such as estrous response, interval and duration of estrus and pregnancy (Table 1). Pregnancy rate combines natural mating and artificial insemination since no differences were observed between both breeding systems (Table 2).

Reproductive end points obtained by ultrasonography are summarized in Table 3. One doe from G6 ovulated before demonstrating signs of estrus and thus it was removed from the statistical analysis.

There was no difference $(\mathrm{P}>0.05)$ between nulliparous and lactating goats on the following end points, respectively: interval to estrus $(23.2 \pm 2.7 ; 28.3 \pm 3.5$ hours $)$, estrous duration $(23.2 \pm 3.0 ; 26.8 \pm 5.6$ hours $)$, ovulation rate [80.0\% (12/15); 86.7\% (13/15)], number of ovulations $(1.7 \pm 0.2 ; 1.5 \pm 0.1)$, interval from device removal to ovulation (54.0 $\pm 3.8 ; 51.0 \pm 2.2$ hours), interval from estrus to ovulation $(30.0 \pm 2.3 ; 27.6 \pm 2.6$ hours $)$, largest follicle diameter $(5.6 \pm 0.1 ; 5.9 \pm 1.1 \mathrm{~mm})$ and pregnancy rate $[66.7 \%$ (10/15); 60.0\% (9/15)].

A positive correlation was detected $(\mathrm{r}=0.66 ; \mathrm{P}<0.05)$ between the cervical mucus at the moment of AI and prolificacy.

Table 2 - Pregnancy rate, parturition rate and fetal loss rate in anestrous Saanen goats subjected to estrous induction receiving progestagen sponges for $6(\mathrm{G} 6), 9(\mathrm{G} 9)$ or 12 (G12) days

\begin{tabular}{lcccc}
\hline Groups & $\begin{array}{c}\text { Breeding } \\
\text { system }\end{array}$ & $\begin{array}{c}\text { Pregnancy } \\
\text { rate }(\%)\end{array}$ & $\begin{array}{c}\text { Parturition } \\
\text { rate }(\%)\end{array}$ & $\begin{array}{c}\text { Fetal loss rate } \\
(\%)\end{array}$ \\
\hline G6 & AI & $3 / 5(60.0)$ & $1 / 3(33.3)$ & $2 / 3(66.7)$ \\
& NM & $3 / 5(60.0)$ & $3 / 3(100.0)$ & $0 / 0(0.0)$ \\
& Total & $6 / 10(60.0)$ & $4 / 6(66.7)$ & $2 / 6(33.3)$ \\
G9 & AI & $5 / 5(100.0)$ & $5 / 5(100.0)$ & $0 / 0(66.7)$ \\
& NM & $3 / 5(60.0)$ & $2 / 3(66.7)$ & $1 / 3(33.3)$ \\
& Total & $8 / 10(80.0)$ & $7 / 8(87.5)$ & $1 / 8(12.5)$ \\
G12 & AI & $1 / 4(25.0)$ & $1 / 1(100.0)$ & $0 / 0(0.0)$ \\
& NM & $4 / 6(66.7)$ & $3 / 4(75.0)$ & $1 / 4(25.0)$ \\
& Total & $5 / 10(50.0)$ & $4 / 5(80.0)$ & $1 / 5(20.0)$ \\
\hline
\end{tabular}

$\mathrm{AI}$ - artificial insemination; NM - natural mating.

$\mathrm{P}>0.05$.

Table 1 - Sexual behavior end points in anestrous Saanen goats subjected to estrous induction receiving progestagen sponges for 6 (G6), 9 (G9) or $12(\mathrm{G} 12)$ days $($ mean $\pm \mathrm{SD})$

\begin{tabular}{lcccc}
\hline \multirow{2}{*}{ Variables } & \multicolumn{3}{c}{ Treatment groups } \\
\cline { 2 - 5 } & G6 & G9 & G12 & Average/Total \\
\hline Estrous response (\%) & $90.0(9 / 10)$ & $100.0(10 / 10)$ & $100.0(10 / 10)$ & $96.7(29 / 30)$ \\
Interval to estrus (h) & $26.7 \pm 16.7$ & $25.2 \pm 8.8$ & $25.2 \pm 10.5$ & $25.7 \pm 11.9$ \\
Duration of estrus (h) & $28.5 \pm 20.2$ & $21.6 \pm 9.5$ & $25.2 \pm 19.1$ & $24.9 \pm 16.3$ \\
Pregnancy rate (\%) & $60.0(6 / 10)$ & $80.0(8 / 10)$ & $50.0(5 / 10)$ & $63.3(19 / 30)$ \\
\hline
\end{tabular}

SD - standard deviation; $\mathrm{h}$ - hours.

Number of animals in parentheses.

$\mathrm{P}>0.05$. 
Table 3 - Reproductive end points obtained by ultrasonography in anestrous Saanen goats subjected to estrous induction receiving progestagen sponges for 6 (G6), 9 (G9) or 12 (G12) days (mean \pm SD)

\begin{tabular}{lcccc}
\hline \multirow{2}{*}{ Variables } & \multicolumn{3}{c}{ Treatment groups } \\
\cline { 2 - 5 } & $\mathrm{G} 6$ & $\mathrm{G} 9$ & $\mathrm{G} 12$ & Total \\
\hline Interval from estrus to ovulation (h) & $26.4 \pm 5.4$ & $27.6 \pm 8.1$ & $32.6 \pm 9.1$ & $28.9 \pm 8.0$ \\
Ovulation rate (\%) & $80.0(8 / 10)$ & $100.0(10 / 10)$ & $70.0(7 / 10)$ & $83.3(25 / 30)$ \\
Number of ovulations & $1.9 \pm 0.6$ & $1.5 \pm 0.5$ & $1.4 \pm 0.5$ & $1.6 \pm 0.6$ \\
Interval from device removal to ovulation (h) & $44.6 \pm 5.8 \mathrm{a}$ & $52.8 \pm 8.4 \mathrm{~b}$ & $60.0 \pm 12.0 \mathrm{~b}$ & $52.5 \pm 10.5$ \\
Largest follicle diameter (mm) & $5.6 \pm 0.5$ & $5.8 \pm 0.9$ & $5.8 \pm 1.0$ & $5.6 \pm 0.7$ \\
\hline
\end{tabular}

$\mathrm{SD}$ - standard deviation; $\mathrm{h}$ - hours.

Means within rows with different letters varied significantly (SNK test or $\chi^{2}$ test; $\mathrm{P}<0.05$ ).

\section{Discussion}

Estrous response rate was similar among treatments, averaging $96.7 \%$ (29/30), slightly higher than previously obtained in Toggenburg goats by the authors of this study using the same type of progestagen sponges for $6(89.5 \%)$ or $9(84.2 \%)$ days (Fonseca et al., 2005). Our group conducted a similar study with Toggenburg goats and reported $100 \%$ of estrus response regardless of treatment duration (Nascimento, 2009). Evidently, even a shorter treatment of $5 \mathrm{~d}$ was also efficient (83.3\%) for estrus induction in Sannen does (Maffili et al., 2005). Using the long-term treatment (12 d) but with a different sponge (FGA) authors observed $100.0 \%$ of Boer females in estrus (Holtz et al., 2008). According to a previous study, treatment for $5 \mathrm{~d}$ was as effective as $12 \mathrm{~d}$ when both were compared (Knights et al., 2001). Therefore, it is reasonable to describe that a 5-6 d treatment is enough to induce estrus. Reproductive planning, exogenous hormone treatment, animal handling (feeding, health, breed, etc.), environmental conditions and season may be important factors affecting estrous response in goats (Dogan et al., 2008).

Of the 29 goats in estrus, 16 were initially identified in estrus in the morning and 13 at night. This difference was greater in previous reports when $85 \%$ and $73 \%$ of Toggenburg goats showed estrus in the morning using similar protocols with MAP (Fonseca et al., 2005) or CIDR, respectively (Souza et al., 2011). These reports suggest that the onset of estrus in goats is a phenomenon that occurs predominantly at night. Timing of onset of estrus and its influence in the ovulation time should be considered in establishing the optimal time for artificial insemination.

The interval from sponge removal to estrus was similar among treatments, averaging 25.7 hours. This time interval was shorter than previously reported in $6 \mathrm{~d}$ (46 hours) or $9 \mathrm{~d}$ (54 hours) protocols for Toggenburg goats (Fonseca et al., 2005) and slightly longer than 22 hours in Turkish
Saanen goats (Dogan et al., 2008). When using CIDR for estrous synchronization in Toggenburg does, our group observed that $6 \mathrm{~d}$ (29 hours) led to a shorter interval than the $9 \mathrm{~d}$ (34 hours) or $12 \mathrm{~d}$ (32 hours) treatments (Nascimento, 2009). Similar study was conducted in Anglo-Nubian goats for $6 \mathrm{~d}$ (34 hours), $9 \mathrm{~d}$ (29 hours) and $12 \mathrm{~d}$ (31 hours) (Fonseca et al., 2009). It was suggested that fertility decreased significantly for animals which came into estrus later than 30 hours after sponge removal (late estrus) (Baril et al., 1993). The duration of estrus was on average 24.9 hours, shorter than the 37 hours obtained in Toggenburg does by Maffili et al. (2006), 31 hours in Turkish Saanen goats (in the treatment most similar to ours - sponge + eCG + PGF) (Dogan et al., 2008) and 31 hours in Boer goats (Greyling \& Van Der Nest, 2000) and similar (25 hours) to the Alpine breed (Fonseca et al., 2008). This variation can be attributed to differences in breed, nutrition, season, different progestagens, use of gonadotrophins and presence of male after sponge removal and social dominance (Orihuela, 2000; Dogan et al., 2008).

During the anestrous season, the frequency of $\mathrm{GnRH}$ pulses is decreased due to low concentrations of circulating estradiol. There is follicular growth during this period and follicles are responsive to infrequent pulses of LH by the estradiol secretion. The emergence of a follicular wave is attributed to fluctuations in FSH plasma concentrations. The follicles reach pre-ovulatory size but go into atresia (Bartlewski et al., 1998; Karsch et al., 1993). Exposure to high progesterone concentrations accelerates the emergence of a new follicular wave (Menchaca \& Rubianes, 2002). After $6 \mathrm{~d}$ of treatment with progestagen, serum progesterone concentrations decrease to subluteal concentrations $(2 \mathrm{ng} / \mathrm{mL})$ and remain low until its removal. Progesterone subluteal concentrations increase LH pulses but not enough to support pre-ovulatory peak. Thus, the follicle grows excessively, persists for a long period and begins its aging process (Menchaca \& Rubianes, 2004). The current study was conducted in the anestrous season and probably the 
difference of $3 \mathrm{~d}$ among treatments resulted in a greater LH concentration in goats from G6 since, at the moment of PGF administration, progesterone was probably higher in this group as previously observed (Menchaca \& Rubianes, 2004). Therefore, the LH peak was possibly obtained more quickly in G6 does, explaining the earlier ovulation when compared with G9 or G12 females. The interval from sponge removal to ovulation deserves special attention. It was previously reported that AI was performed 45 hours after sponge removal (Corteel \& Leboeuf, 1990) with good results of fertility. However, the authors used a higher dose of eCG, which may have anticipated ovulation allowing a successful use of an earlier insemination, 45 hours in comparison to 48 and 60 hours in the current study.

The number of ovulations (1.6) and diameter of the largest follicle $(5.7 \mathrm{~mm})$ did not differ among treatments. It is well known that P4 concentrations may influence LH and thus long-term treatments can lead to P4 subluteal concentrations, promoting an excessive growth and persistence of largest follicle increasing its age (Menchaca \& Rubianes, 2004). This fact was not observed in the current study perhaps because the long-term treatment used herein was not as extended as in other studies. A total of $83 \%$ of goats ovulated; similar to the $96 \%$ previously described (Souza et al., 2011). One female ovulated before demonstrating estrus signs, perhaps by function of dominant-subordinate relationships (Orihuela, 2000).

In the current study, hCG was administered $5 \mathrm{~d}$ after breeding in order to avoid fetal loss as it has been reported as a potent luteotropic or anti-luteolytic agent in goat (Saharrea et al., 1998). However, a total of 21\% (4/19) of goats lost their fetuses, which is still a high percentage. It was previously suggested that the action of hCG appears to depend on season and parity (Fonseca \& Torres, 2005).

A positive correlation was detected $(\mathrm{r}=0.66 ; \mathrm{P}<0.05)$ between the cervical mucus and the moment of AI and prolificacy. It is known that the ovulation in goats occurs at the end of estrus or also in metaestrus (Souza et al., 2011). After some training it is easy to identify - observing the mucus - in which stage of estrus the female stands and therefore to recommend the use of fresh or frozen semen according to mucus characteristics. It is noteworthy to mention that for frozen semen the most adequate moment to perform $\mathrm{AI}$ is 18 to 24 hours after estrous onset, when the doe has a mucus varying between 3 and 4 (Siqueira et al., 2007). On the other hand, when using fresh semen, AI should be performed at the estrous onset, when mucus is crystalline, in order to obtain higher fertility (Aisen, 2004).

\section{Conclusions}

Protocols using progestagen sponges for 6,9 or 12 days are equally efficient to induce a synchronized estrus during the nonbreeding season in Saanen goats. The identification of ovulation relative to the estrous onset may vary according to the treatment chosen and this moment is very important in order to establish effective protocols of artificial insemination. These new possibilities of estrous induction-synchronization programs are attractive since they allow producers to supply meat and dairy products throughout the year.

\section{Acknowledgments}

Thanks go to National Council for Scientific and Technological Development (CNPq Project 559151/2010-1) and Embrapa (Project 02.08.02.005.00.04) for the financial aid and to Caetano Geraldo de Souza from Capril Santa Clara, Coronel Pacheco, Minas Gerais, Brazil, for his invaluable help.

\section{References}

AISEN, E.G. Reproducion ovina y caprina. Buenos Aires: InterMédica, 2004. 206p.

BARIL, G.; LEBOEUF, B.; SAUMANDE, L. Synchronization of estrus in goats: the relationship between time of occurrence of estrus and fertility following artificial insemination. Theriogenology, v.40, p.621-628, 1993.

BARIL, G.; REMY, B.; LEBOEUF, B. et al. Synchronization of estrus in goats: The relationship between eCG binding in plasma, time of occurrence of estrus and fertility following artificial insemination. Theriogenology, v.45, p.1553-1559, 1996.

BARTLEWSKI, P.M.; BEARD, A.P.; COOK, S.J. et al. Ovarian follicular dynamics during anoestrus in ewes. Journal of Reproduction and Fertility, v.113, p.275-285, 1998.

CORTEEL, J.M.; LEBOEUF, B. Évolution techno-économique de l'insemination artificielle caprine. Elevage Insémination, v.237, p.3-17, 1990.

DISKIN, M.G.; AUSTIN, E.J.; ROCHE, J.F. Exogenous hormonal manipulation of ovarian activity in cattle. Domestic Animal Endocrinology, v.23, p.211-228, 2002.

DOGAN, I.; NUR, Z.; GUNAY, U. et al. Comparison of fluorgestone and medroxyprogesterone intravaginal sponges for oestrus synchronization in Saanen does during the transition period. South African Journal of Animal Science, v.34, p.18-22, 2004.

DOGAN I.; KONYALI, A.; GUNAY, U. et al. Comparison of the effect of cronolone sponges and PMSG or cloprostenol on estrous induction in Turkish Saanen goats. Polish Journal of Veterinary Sciences, v.11, p.29-34, 2008.

FONSECA, J.F.; BRUSCHI, J.H.; SANTOS, I.C.C. et al. Induction of estrus in non-lactating dairy goats with different estrous synchrony protocols. Animal Reproduction Science, v.85, p.117-124, 2005.

FONSECA, J.F.; TORRES, C.A.A. Administration of hCG 5 days after breeding and reproductive performance in nulliparous dairy goats. Reproduction in Domestic Animals, v.40, p.495-499, 2005.

FONSECA, J.F.; LOBO, R.N.B.; FACÓ, O. et al. Timed artificial insemination (TAI) in Saanen goats. Reproduction in Domestic Animals, v.42, p.139, 2007. 
FONSECA, J.F.; SIMPLÍCIO, A.A. Inseminação artificial e transferência de embriões em caprinos e ovinos. In: ENCONTRO INTERNACIONAL DA PECUÁRIA DA AMAZÔNIA, 1., 2008, Belém. Anais... Belém, 2008. p.15-23.

FONSECA, J.F.; TORRES, C.A.A.; SANTOS, A.D.F. et al. Progesterone and behavioral features when estrous is induced in Alpine goats. Animal Reproduction Science, v.103, p.366-373, 2008.

FONSECA, J.F.; SOUZA, J.M.G.; RIBEIRO, A.C. et al. Estrus and fertility of anestrous Anglo-Nubian goats submitted to different synchronous protocols and given hCG five days after artificial insemination. In: CONGRESSO BRASILEIRO DE REPRODUÇÃO ANIMAL, 18., 2009, Belo Horizonte. Anais... Belo Horizonte, 2009. p.408. (CD-ROM).

GINTHER, O.J.; KOT, K. Follicular dynamics during the ovulatory season in goats. Theriogenology, v.42, p.987-1001, 1994.

GREYLING, J.P.C.; VAN DER NEST, M. Synchronization of oestrus in goats: dose effect of progestagen. Small Ruminant Research, v.36, p.201-207, 2000.

HERVÉ, V.; ROY, F.; BERTIN, J. et al. Antiequine chorionic gonadotropin (eCG) antibodies generated in goats treated with ecg for the induction of ovulation modulate the luteinizing hormone and follicle-stimulating hormone bioactivities of eCG differently. Endocrinology, v.145, p.294-303, 2004.

HOLTZ, W.; SOHNREY, B.; GERLAND, M. et al. Ovsynch synchronization and fixed-time insemination in goats. Theriogenology, v.69, p.785-792, 2008.

KARSCH, F.J.; DAHL, G.E.; EVANS, N.P. et al. Seasonal changes in gonadotropin-releasing hormone secretion in the ewe: Alteration in response to negative feedback action of estradiol. Biology of Reproduction, v.49, p.1377-1383, 1993.

KNIGHTS, M.; MAZE, T.D.; BRIDGES, P.J. et al. Short-term treatment with a controlled internal drug releasing (CIDR) device and FSH to induce fertile estrus and increase prolicifacy in anestrous ewes. Theriogenology, v.55, p.1181-1191, 2001.

LEBOEUF, B.; MANFREDI, E.; BOUE, P. et al. Artificial insemination of dairy goats in France. Livestock Production Science, v.55, p.193-203, 1998.

MAFFILI, V.V.; TORRES, C.A.A.; FONSECA, J.F. et al. Sincronização de estro em cabras da raça Saanen com esponja intravaginal e CIDR-G ${ }^{\circledR}$. Arquivo Brasileiro de Medicina Veterinária e Zootecnia, v.57, p.591-598, 2005.

MAFFILI, V.V.; TORRES, C.A.A.; BRUSCHI, J.H. Indução de estro em cabras da raça Toggenburg com dois diferentes dispositivos intravaginais. Arquivo Brasileiro de Medicina Veterinária e Zootecnia, v.58, p.367-372, 2006.

MENCHACA, A.; RUBIANES, E. Relation between progesterone concentrations during the luteal phase and follicular dynamics in goats. Theriogenology, v.57, p.1411-1419, 2002.

MENCHACA, A.; RUBIANES, E. New treatments associated with timed artificial insemination in small ruminants. Reproduction, Fertility and Development, v.16, p.403-413, 2004.

NASCIMENTO, P.M.P. Indução de estro sincronizado em cabras da raça Toggenburg com protocolos de curta, média e longa duração no anestro estacional e acasalamento natural. 2009. 100f. Dissertação (Mestrado em Mediciba Veterinária) Universidade Federal Fluminense, Niterói.

NATIONAL RESEARCH COUNCIL - NRC. Nutrient requirements of goats. Washington, D.C.: National Academy of Sciences, 2007. $384 \mathrm{p}$.

ORIHUELA, A. Some factors affecting the behavioural manifestation of oestrus in cattle: a review. Applied Animal Behaviour Science, v.70, p.1-16, 2000.

PEEL, M.C.; FINLAYSON, B.L.; MCMAHON, T.A. Update world map of the Koppen-Geiger climate classification. Hydrology and Earth System Sciences, v.11, p.1633-1644, 2007.

RIBEIRO JÚNIOR, I. Análises estatísticas no SAEG. Viçosa, MG: Editora UFV, 2001. 301p.

ROMANO, J.E. Synchronization of estrus using CIDR, FGA or MAP intravaginal pessaries during the breeding season in Nubian goats. Small Ruminant Research, v.55, p.15-19, 2004.

SAHARREA, A.; VALENCIA, J.; BALCÁZAR, A. et al. Premature luteal regression in goats superovulated with PMSG: Effect of hCG or GnRH administration during the early luteal phase. Theriogenology, v.50, p.1039-1052, 1998.

SIQUEIRA, A.P.; FONSECA, J.F.; SILVA FILHO, J.M. et al. Parâmetros reprodutivos de cabras Toggenburg inseminadas com sêmen resfriado, após diluição em meio a base de gema de ovo. Acta Scientiae Veterinariae, v.35, p.1036, 2007.

SOUZA, J.M.G.; TORRES, C.A.; MAIA, A.L.R.S. et al. Autoclaved, previously used intravaginal progesterone devices induces estrus and ovulation in anestrous Toggenburg goats. Animal Reproduction Science, v.129, p.50-55, 2011.

VIÑOLES, C.; FORSBERG, M.; BANCHERO, G. et al. Effect of long-term and short-term progestagen treatment on follicular development and pregnancy rate in cyclic ewes. Theriogenology, v.55, p.993-1004, 2001. 